\title{
Steroid-responsive vasculitis and arthritis in meningococcal septicaemia
}

\author{
P. W. N. KeELING \\ M.R.C.P.I., M.R.C.P.
}

\author{
N. O. Aston \\ M.B., B.Chir.
}

\author{
D. N. CROFT \\ D.M., F.R.C.P.
}

Gastrointestinal Research Unit, The Rayne Institute, St Thomas' Hospital, London, SEl 7EH

\begin{abstract}
Summary
The case of a 42-year-old West Indian woman with meningococcal septicaemia and steroid-responsive immune complex disease is reported.

\section{Introduction}

Meningococcal infection may present as meningitis or as acute-fulminating, subacute or chronic sepicaemia. There may be associated arthritis, vasculitis, episcleritis and intravascular coagulation (Whittle et al., 1973). Such complications which usually occur between 3 and 10 days from the onset of the illness, when patients are otherwise improving, have been attributed to immune complex deposition (Greenwood, Whittle and Bryceson, 1973). The authors report a case of severe meningococcal septicaemia in which these complications responded rapidly to corticosteroids.
\end{abstract}

\section{Case report}

A 42-year-old West Indian woman presented with a one-day history of malaise, sore throat and rigors. Clinically she was alert with no signs of meningitis. She was pyrexial $\left(39 \cdot 4^{\circ} \mathrm{C}\right)$ with a tachycardia but normal BP. Laboratory findings were $\mathrm{Hb}, 11.4 \mathrm{~g} / \mathrm{dl}$; white cells, $3.3 \times 10^{9} / 1$; platelets, $220 \times 10^{9} / 1$; sickle test negative; ESR $15 \mathrm{~mm} / \mathrm{hr}$ (Westergren). Lumbar puncture yielded clear CSF; cells $<10^{6} / 1$; protein $40 \mathrm{~g} / \mathrm{l}$; Gram stain negative. Initial treatment with ampicillin was changed to i.v. penicillin and sulphadimidine when blood culture grew a group B Neisseria meningitidis.

On the 2 nd day of admission she developed severe pain in her knees, shoulders and wrists, and on the following day a purpuric rash on the limbs and trunk. Laboratory findings then were: $\mathrm{Hb}, 9.5 \mathrm{~g} / \mathrm{dl}$; white cells, $10.9 \times 10^{9} / 1$; platelets, $80 \times 10^{9} / 1$; prothrombin time ratio, 2.1 (normal $<1.3$ ); partial thromboplastin time, $14.7 \mathrm{sec}$ (normal -3.9 to +19.9 $\mathrm{sec}$ ); fibrin degradation products, $1: 32$ (normal $1: 8)$.

Painful indurated papules appeared on her buttocks on the 5th day, when the ESR was $60 \mathrm{~mm}$ and the serum $\mathrm{C} 3$ concentration was reduced $(0.68$ $\mathrm{g} / \mathrm{l})$. The lesions spread to involve the abdomina wall and left arm and so the patient was given i.vo hydrocortisone, $400 \mathrm{mg}$. daily. Within $24 \mathrm{hr}$ the arthropathy resolved, the temperature was norma and the papules had improved. No further skir lesions developed and repeated coagulation studies were normal.

\section{Comment}

Patients who develop allergic complications after a meningococcal infection may have circulating antibodies (Greenwood et al., 1973). Early in a meningococcal infection there may be free circulating meningococcal antigens, but secondary features develop later when the corresponding antibody concentrations rise, coinciding with a fall in complement levels (Greenwood, Onyewotu and Whittle, 1976). Immune complexes have been found at this time both in serum (Davis et al., 1976) and in synovial fluid from affected joints (Larson et al., 1977). In 1973, Greenwood et al. suggested that the manifestations of meningococcal disease associated with immune complexes could be modified by the use of corticosteroids.

The present patient developed complications secondary to a meningococcal septicaemia: she had a cutaneous vasculitis, arthropathy and disturbed coagulation with a high ESR and lowered serum $\mathrm{C} 3$, and she responded as predicted when treated with steroids. This experience indicates that steroids can be helpful in the management of immune complex-associated meningococcal disease. 


\section{References}

Davis, J.A.S., Peters, N., Idris, Mohammed, Major, G.A.C. \& Holborow, E.J. (1976) Circulating immune complexes in a patient with meningococcal disease. British Medical Journal, 1, 1445.

Greenwood, B.M., Onyewotu, I.I. \& WhitTle, H.C. (1976) Complement and meningococcal infection. British Medical Journal, 1, 797.

Greenwood, B.M., Whittle, H.C. \& Bryceson, A.D.M. (1973) Allergic complications of meningococcal disease II.
Immunological investigations. British Medical Journal, 1, 737.

Larson, H.E., Nicholson, K.G., Loewi, G., Tyrrell, D.A.J. \& Posner, J. (1977) Arthritis after meningococcal meningitis. British Medical Journal, 1, 618.

Whittle, H.C., Abdullahi, M.T., Fakunie, F.A., GreenWOOD, B.M., BRYCESON, A.D.M., PARRY, E.H.O. \& TURK, J.L. (1973) Allergic complications of meningococcal disease. I. Clinical aspects. British Medical Journal, 2, 733 . 